\title{
THE CONCEPT OF WAQF-SYIRKAH FOR COMMUNITY FOOD SECURITY
}

\author{
Muhammad Dandy Alif WILDANA ${ }^{1 *}$ \\ $A n^{\prime} \mathrm{im}$ KAFABIH ${ }^{2}$
}

\begin{abstract}
Received: January 2021 | Accepted: February 2021 | Published: April 2021
\end{abstract}
Please cite this paper as: Wildana, M.D.A., Kafabih, A. (2021) The concept of Waqf-Syrkah for commodity food security, Holistica Journal of Business and Public Administration, Vol.12, Iss.1, pp.76-88

\begin{abstract}
Food is essential for human survival, and ensuring its availability is critical. Waqf is present as one of supporting institutions that supports food security. This paper aims to see how waqf can contribute to the food security of a community. Waqf, in its sense is an Islamic philanthropic institution that focus on welfare of Muslim. As a Muslim, it is important to safeguard one's life as stated in Maqasid As Shariah. This paper employs systematic literature review to see the contribution of waqf through syirkah (partnership) for community food security. Syirkah plays its role as a connector between waqf and food security, with farmers at its spearhead. Syirkah is chosen because it is compatible with farmer's business and waqf may serve to their business sustainability in general, and farmer's livelihood in particular. The ultimate goal of this concept is to achieve stability in the supply of staple food which leads to its price stability, hence staple food is available and accessible to all. Furthermore, the stability achieved will reduce the burden of government to provide staple food in times of crisis and to promote welfare and better social cohesion of a community.
\end{abstract}

Keywords: Waqf; Food Security; Maqasid As Syariah; Syirkah

\section{Introduction}

FORDEBI (Islamic Economics and Business Lecturer Forum) proposed a concept of welfare known as "Kesejahteraan Semesta", or in English "universal wellbeing" on December, $5^{\text {th }}$, 2016. The main goal of that concept is to affirm tawhid through falah as its intermediate goal. 'In Qur'anic verse, the term falah can be defined from Al- Baqarah verse 201 where

\footnotetext{
${ }^{1}$ Faculty of Economics and Business, Universitas Brawijaya, Malang, Indonesia, dandyalif.feb.ub@ub.ac.id.

* Corresponding author.

${ }^{2}$ Faculty of Economics and Business, Universitas Brawijaya, Malang, Indonesia, animkafabih@ub.ac.id.
} 
the translation is "...,Our Lord, give us good in this world and good in the Hereafter, and shield us from the punishment of the Fire!" (Nasr, 2015). Khan (1984) explained that falah can be defined as a word that represents three things; these are: survival, freedom of want, and power of honour.

To achieve falah as an intermediate goal in this universal well-being concept, Mulawarman et al (2018b) proposes several principles that must be followed, one of them is maqasid shariah as a base of universal wellbeing. This means that universal wellbeing can be achieved through achievement of 7 indicators of maqasid shariah which are religion, aql, soul, wealth, offspring social, and environment (Mulawarman et al, 2018b).

Furthermore, to implement universal wellbeing concept Mulawarman et al (2018b) suggests several real sectors in economy that should be studied to identify the main problems of each sector, one important sector that must be considered much is agriculture. Agricultural sector is highly related to food security, and whether the availability of food can feed humans around the world becomes the main question that must be taken into consideration.

Based on Robert Malthus's prediction, human population growth will be outstripped food production. This prediction in fact highlights the importance of food security to ensure that food is enough for human beings. Research shows that based on Raconteur (2017)'s projection, in 2050 the number of populations in the world will reach almost 10 billion people and become 12 billion in the year of 2100 . Hence, in less than 100 years, the population will increase $71 \%$ from the current population that is around 7 billion people.

In terms of food calories intake, Raconteur (2017) shows that the total calories consumed in 1970 is less than 2500 per person, and in 2010 increased to 2750 per person. The projection in 2050 shows that total calories needed per person reach beyond 3000 . If this calories projection is multiplied by 10 billion people, which is a population growth projection in 2050 , the projection shows that the world requires a great deal of food that must be prepared to fulfil calories of all populations.

As explained briefly before, universal wellbeing has several principles that should be followed to generate falah as an intermediate goal to affirm someone's tawhid. One other principle in universal wellbeing concept is "all kinds of mandated resources in essence are donated in the form of waqf ". Land that in the end produces staple food resources (rice, wheat, maize, etc) is a mandated resource from Allah (God) and humans must manage them fairly. Based on that principle of universal well-being concept, waqf might be a solution to cope with fundamental problems of food security, especially when it is related to availability, affordability, and quality and safety. Therefore, the goal of this study is to introduce waqf-syirkah framework in universal wellbeing framework as a solution for food security problems.

In the next section, this paper explains the global snapshots for food security issues and key highlights. In the following sections, this paper explains the connection between food security and maqasid as-shariah as the goal for Muslims, and it will be followed by brief 
explanation of waqf institution as Islamic charitable institution that become the very foundation of this paper. In the subsequent section, this paper explains the proposed waqf-syirkah framework for community food security, focusing on how waqf institutions contribute to the farmers and community food security altogether. The last two sections of this paper explain justification of the proposed framework and the conclusion of this paper.

\section{Food Security: Global Snapshots}

The Food and Agriculture Organisation (FAO) in 1996 defined food security as when people have physical and economical access to safe, nutritious foods, that are able to fulfil daily dietary needs to ensure active and healthy life. Furthermore, FAO detailed the dimensions of food security into four:

1. Food availability: Food is available in sufficient quantity and quality through domestic produce or through import from other countries.

2. Food access: Food is accessible by individuals and able to acquire necessary food for nutritious daily diet.

3. Food utilization: Food is utilized through adequate diet and calories intake, availability of clean water access, proper sanitation, and healthcare services to reach an emotional well-being where all physiological needs are met.

4. Food stability: A person, a household or a community must have access to food all times to be considered as food secure conditions. Stability refers to availability and access dimension of food security.

Beside FAO as an international body under the United Nations that mostly provide data for food, there are other organisations that have the same or even greater concern regarding food related issues. One of the leading institutions in highlighting and reporting food security issues and data is The Economist, with its branch of Economist Intelligence Unit (EIU) titled Global Food Security Index (GFSI). In 2019, the top three ranks in EIU GFSI are Singapore, Ireland, and the United States of America. These three countries are ranked based on three aspects: affordability, availability, and quality and safety of food. Unfortunately, the bottom countries on the list are countries that have been experiencing political and economic instability namely: Syria, Burundi, and Venezuela. In addition to ranking countries globally, EIU GFSI also highlights several key aspects in food security issues.

EIU GFSI highlights that developed nations are more advanced compared to developing nations in food security index because they have better resources and infrastructure to support three pillars set out by EIU GFSI (Economist Intelligence Unit, 2019a; 2019c). For example, EIU reports that among 113 countries listed in the index, only $30 \%$ of it has proper irrigation, while the remaining $70 \%$ of the countries have $10 \%$ or less irrigation systems (Economist Intelligence Unit, 2019a). The issue of irrigation is crucial, because 
food crops require at least $70 \%$ of water to be able to grow properly (Economist Intelligence Unit, 2019b). Without an irrigation system, crops have less water which results in less production, and this issue becomes more serious with longer draught season and shorter wetter rainy season because of climate change that alter the pattern of weather globally. This irrigation issue cannot be handled solely by farmers themselves, but it needs help from the government because building irrigation systems requires costly investment. However, EIU noted that public expenditure on agriculture decreased steadily from 2000 until 2016 globally, and this can further deteriorate the food security, especially in developing nations (Economist Intelligence Unit, 2019a).

In 2050, EIU forecasts that the global world faces a declining supply of food and water, while at the same time facing the growth of the worldwide population to 9.7 billion people. ElU forecasts that in 2050, we face $10 \%-25 \%$ decline in food crop yield, $60 \%$ more crop production with an extra $15 \%$ water requirement to cater to global population increase (Economist Intelligence Unit, 2019b). The conflict of people vs food crop is inevitable, because more people translate to more water required while they also need to be fed too. Although EIU has projected grim future for food security, the issue of food wastage and loss are still looming globally, with a significant loss recorded every year. EIU using FAO data stated that between 2000-2016 there is 1.3 billion tonne/year food is either wasted or lost, while its production contributes to $8-10 \%$ of greenhouse gases during that year (Economist Intelligence Unit, 2019a). This issue of food loss and wastage, according to EIU in its report caused by human behaviour and insufficient storage facility, because food products require proper storage because it is considered as perishable items (Economist Intelligence Unit, 2019a).

Another important issue in food security is the lack of financing options for farmers which resulted in decreasing food production supply thus increasing its price (Economist Intelligence Unit, 2019a). ElU reported that among 113 countries listed, 30\% of them have limited to no financing at all. Furthermore, the EIU also highlighted that in light of climate change that affects crop yield, $46 \%$ of the countries surveyed has no financial protection from risks of crop destruction due to natural disasters caused by climate change (Economist Intelligence Unit, 2019a).

The financing problem is common in the agriculture sector, especially small to medium scale farmers due to their inability to provide collateral and lack of financial literacy among them (Moh'd et al, 2017). It is important for farmers to receive enough support, by both public and private institutions to ensure the production of food crops are sufficient to secure food supply and strengthen food security (Wildana, 2018).

\section{Food Security and Maqasid As Shariah}

The term maqasid shari'ah (objective of Shari'ah) originated from two words (Maqas, or Maqsid and the term Shari'ah) [Shinkafi and Ali, 2017]. Based on Shinkafi and Ali (2017), the term Maqas or Maqsid refers to "objective, wisdom, intent or purpose" and as that 
word is combined by the term Shari'ah, literally maqasid shari'ah mean "path" "way" or "a path to a watering place", and also it can be translated to "Islamic law" (Shinkafi and Ali, 2017).

Shari'ah aims at the acquisition of what is good and beneficial (jalb al-masalih or maslahah) and the rejection of what is evil and harmful (dar' al-mafasid or mafsadah) [lbn Ashur, 2006]. One classification of maslahah based on its quality is the indispensable masalih (daruriyyah) where it is explained as things whose realization is essential for the community both collectively and individually (Ibn Ashur, 2006). Furthermore, Al Ghazali, Ibn al Hajib, al-Qarafi and al-Shatibi describe in detail that category of daruri consists of preserving and safeguarding (hifz) of religion (din), life (nufus), intellect (uqul), property (amwal), lineage (ansab), and some jurists also add preservation of honor (ird) [lbn Ashur, 2006].

Mulawarman et al. (2018b) explains that in the universal well-being concept, there are 6 principles as a guideline for humans to act where principle number 5 states that the achievement of universal well-being is based on seven aspects of maqasid shari'ah. Mulawarman et al. (2018a) 7 aspects of maqasid shari'ah proposed by Mulawarman et al. (2018b) are the same as what explained by Ibn Ashur (2006) such as safeguarding (hifz) of religion (din), life (nufus), intellect (uqul), property (amwal), lineage (ansab), but Mulawarman et al (2018a) add 2 others aspect, viz environment, and social.

Furthermore, as principle of universal well-being number 2 is explaining about mandating all kind of resources in the form of waqf, and principle number 5 is about universal wellbeing achievement which is based on seven aspect of maqasid shariah as explained in previous paragraph, then this paper try to articulate principle number 2 and 5 in universal wellbeing concept by highlighting waqf activities that should be directed to fulfil 7 aspect of maqasid shari'ah.

Agricultural sector as one field of what universal wellbeing concept can be implemented to solve some problems about it, is highly related to food security. It is believed that food security has any relation to maqasid shari'ah. Meaning that as problems in food security are fixed, then maqasid shariah can be achieved.

Pawlak and Kolodziejckzak (2020) explain that ensuring food security has become an issue of key importance to countries with different degrees of economic development, while the agricultural sector plays a strategic role in improving food availability. Food is a necessary thing to someone or even society to keep themselves alive. As food can be acquired with an affordable price, and supply of food is not volatile, then food availability will impact directly on several aspects in maqasid shari'ah.

As Ghosh (2021) explains, the brain needs optimal nutrients intake. Nutrients are essential for human health and physiological functioning whereas the human body cannot synthesize certain nutrients internally, they need to be complemented from food (Ghosh, 2021). Based on that explanation, as people obtain enough food supply, their brain then gains optimal nutrients intake, this situation enabling them to preserve their life, intellect, 
their property, and their lineage. Cordero (2016) from Terre des hommes explains the difference among the progress on food security. Food security is important to fight poverty and hunger among society. Therefore, as food supply is available for all, then social aspects can be maintained and preserved.

Furthermore, when their calories are fulfilled, humans can do whatever activities which make them closer to God such as paying zakah, praying, helping others, and so on. This might happen in some countries in which people there say religion is very important in their lives. Based on PEW research centre (2018) there are high percentages on the importance of religion in several countries namely: Ethiopia (99\%), Ghana (97\%), Thailand and Kenya (95\%), Pakistan and Nigeria (94\%), Indonesia (93\%) and so on.

Negi (2005) found that religious beliefs and rituals are very much inter-linked and intimately related to management of ecosystems where religion forwards the conservations of natural biodiversity in several different ways. As food supply determines the state of health and this condition will affect activity related to religion as explained in the previous paragraph, based on Negi (2005) study, religion will affect the environment in the form of conservation of natural biodiversity.

\section{Waqf: Islamic Charity}

Waqf in definition is to hold and confine certain type of assets or property whereby the benefit generated from the asset is distributed as per stipulated in the waqf deed written by its giver (Kahf, 2016). After an asset is made waqf, then its ownership is automatically transferred to Allah, whereby waqf acts as the trustees of the asset. After that, the managers that work in the waqf institution are responsible to maintain, develop and utilize the asset ether to maintain the condition of the asset itself and/or to provide benefit to the rightful recipients (Mauquf 'Alaih). In general, assets made waqf are in the form of non-perishable form, thus the enjoyment of the benefits does not impair the asset itself, as long as the asset is maintained properly (Kahf, 2016).

Most of waqf assets surrendered by Muslim is commonly used for religious purposes, whereas waqf itself can be classified into two more categories: Charitable, and Family (Kahf, 2016). Waqf in its form as a charitable institution serves as the provider for socioeconomic development of the community by contributing to the public interest such as school, healthcare, housing, and many more. This argument is supported by Çizakça, (1998) that explain that waqf plays a pivotal role as the provider of public goods instead of the government at that time. The final form is family waqf, where the benefit of the waqf asset is either exclusively given to the descendant of the waqif, or shared with the public. In the event all descendants have deceased, then the waqf asset is managed under waqf board and its benefits are all channelled for public interest.

Islahi (1996) and Çizakça, (1998) argue that in the past, waqf served as both provider for public goods and investor for private venture capital. The success of waqf as the provider for both public and private interest shows its versatility and agility to fit into the void 
where the government is supposed to fill, and act as both government backup and/or incentives. Furthermore, Kahf (n.d) argued that it is not forbidden for waqf to turn itself to be a profit-oriented institution, as long as it serves public interest. One of the examples of profit-oriented waqf institution is based on the research of Noor et al (2018) on waqf institution in Malaysia, and managed to classified them as Social Business Type I and Type II.

In type I Waqf set up a business and became either owner or investor of the company. All profit earned from the business is used for solving social issues, and waqf institutions only take initial capital without any profit attributed to it. In the Type II, waqf became capital provider for the poor and underprivileged to open-up or expand their ventures or businesses. The profit received from the businesses are given entirely to the business owners to improve their livelihood (Noor et al, 2018). The most common type in Malaysia is type II, where mostly waqf assets are managed by State Islamic Religious Councils, where they develop profit-generated projects, and redistribute it either to new businesses or improving the current one (Noor et al, 2018).

The concept of waqf-syirkah is more inclined into type II waqf as explained by Noor et al (2018), where waqf provides most of the capital needed for farmers to do agricultural activities. However, the profit earned is shared between waqf and farmers as its partner based on pre-agreed ratio upfront, where mostly the profit is given to farmers to increase their livelihood.

\section{Waqf-Syirkah Concept for Community Food Security}

The original proposal of creating waqf-based food security is based on Abldelhady (2017) who sees the potential of food security issues in the Middle East area. Furthermore, he emphasizes that the governments of Middle Eastern countries are required to set up cross-jurisdiction waqf that can operate in most of the countries there, considering that not every country in the Middle East has arable area that can be used to plant essential food crops for consumption and food security measures (Abdelhady, 2017).

An example of waqf land utilization proposal can be seen in Indonesia, the largest muslim country in the world. The initial proposal for using waqf land under the supervision of Indonesian Waqf Board (Badan Wakaf Indonesia) to be utilized for paddy fields (Puspitasari, 2017). The main goal of producing enough supply of rice in Indonesia is to close the gap between the basic prices on farmers compared to retail price in the market (Puspitasari, 2017). However, there is no mention whether the land under the trusteeship of Indonesian Waqf Board is all arable or not, and the land itself is spread across Indonesian island, from Sumatra to Papua.

Another example of land utilization initiative is from Rastin Profit and Loss Sharing (PLS) Banking Proposed by Bidabad (2019). Islamic banking in its nature is a financial institution that works under sharia principles providing financing to businesses (Sudarsono, 2003 in Andreas and Wohon, 2019). In this perspective, Rastin PLS Banking concocted an initiative 
HOLISTICA Vol 12, Issue 1, 2021, pp.76-88

to revive uncultivated land, to become productive and can generate income to those who utilize it. Bidabad (2019) opine that the source of the uncultivated land may come from the government and Islamic banks can finance the project of reviving it.

After the land has been restored and rejuvenated, the government, according to Bidabad (2019) may transfer the ownership of the restored land to the restorer agent, or it is shared between the restorer and the bank (Rastin) if the project is financed by Rastin bank. The form of land restoration can be in the form of agriculture, housing, industry, commercial, mining, tourism, and/or other activities that may generate income and make use of the land. However, the ownership of the revived land must be in accordance with the regulation where it is implemented, and in this example is Iran (Bidabad, 2019), and it may vary from one country to another, because each country has its own regulation on land ownership.

The concept of waqf-syirkah is proposed to utilize waqf land that is not used and arable to grow crops that produce staple food that is consumed by the community who grows it with the help of farmers as its spearhead. The cooperation between waqf and farmers are based on even-footing and mutual in nature, because in one side, waqf has the capital that are idle, and on the other is farmers who cultivate, grow, and harvest the crop grown on said land, under Islamic cooperation contracts, namely mudharabah (venture capital) and musharakah (partnership). The framework of waqf-syirkah concept is as follows:

Figure 1 Waqf-syirkah Concept

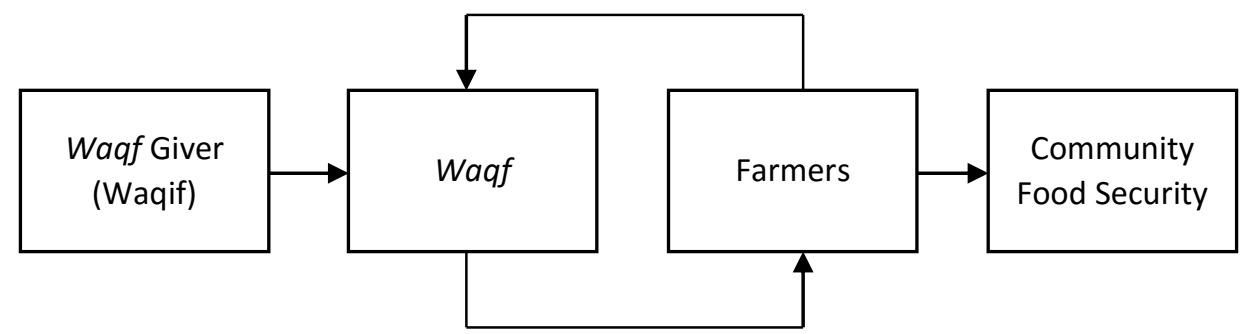

Source: Author's synthesis, 2020

The concept is explained as follows:

1. Asset owner (waqif) surrenders his asset (i.e land) to waqf to be managed. The land will be observed by waqf whether the land is arable or not. If the land is considered as arable, then it can be utilized to plant food crops.

2. Waqf as the trustees of the land enters into partnership with farmers.

3. Waqf and farmer choose the most suitable option based on the profile of the farmer. If the said farmer owns no capital, then mudarabah (venture capital) contract is chosen. In another case, if the farmer has some capital to cultivate the land, musharakah (partnership) contract is chosen. 
HOLISTICA Vol 12, Issue 1, 2021, pp.76-88

4. Waqf and farmer shared profit and loss based on the chosen contract and based upon pre agreed ratio upfront.

5. Waqf share of crops is either deposited in its original form as reserve or can be sold and converted into cash for either economic, social, or religious purposes.

6. The reserve held by waqf in the form of original staple food crops such as rice, maize, whey, barley, etc are considered as stock to ensure food security of the community in the smallest form.

In this concept, the treatment of waqf is no longer limited into religious and charitable institutions as it supposed, but more into the commercial side, while retaining its original purposes. The trend of waqf institutions adopting this approach is due to ensure the sustainability of the waqf itself (Noor et al, 2018). Without stable and adequate source of income, it is impossible for waqf to maintain itself and its assets, let alone its noble goal as the protector of Muslim wealth and the anchor for social-economic interest of Muslim people. Hence, waqf must be creative and put efforts to create ventures or businesses to earn profit that can serve its cause.

Mudarabah and musharakah are chosen because partnership contracts can redistribute and reallocate business resources compared to other contracts and give more benefit to the underprivileged (Choudhury, 1992). With mudarabah and musharakah, farmers have less worries regarding capital and solely focus on cultivating the land to produce optimum harvest of food crops. However, the employment of partnership contracts is prone to principal agency issues, because it requires highly ethical value from both sides for the business to run smoothly without hindrance (Moh'd et al, 2017).

Hence, it is essential for both sides to honour the partnership agreement they signed and waqf as the guardian of Muslim public interest has to be very vigil to ensure there will be no fraud and concealment in the partnership. Moreover, Moh'd et al (2017) emphasizes that partnership contracts can be used to help the poor and resource-depleted farmers to obtain financing for their agriculture businesses and increase their output. In addition, partnerships also help them to avoid interest-bearing, collateralized based financing and its intricacies, because most of the farmers, especially in the developing countries are mostly financially illiterate (Moh'd et al, 2017).

Implementation of Waqf-Syirkah concept does not come without hindrances. The first hindrance is the issue of land ownership regulation. Waqf properties (land and other equipment) philosophically belong to Allah (God), but in practice the ownership name written in legal documentation is under the board of trustees that manages waqf and its managers. The inconsistencies and lack of proper regulation may hinder the operations, especially when the surrendered land is under legal suit either by its previous owners, the heirs of the asset, or other party. Proper regulation to protect waqf land is desperately needed. 
HOLISTICA Vol 12, Issue 1, 2021, pp.76-88

The next issue that has to be addressed is the issue of protection of the crops in the event of loss either caused by natural disasters or other factors. There is a possibility of Islamic insurance company (Takaful) may step in to provide protections, but due to the nature of the risk, a Takaful company may charge a high amount of contribution to counter the risk it absorbed. There is an urgent need for suitable protection for the crops grown by farmers.

The last issue that must be taken into account is the issue of competition with other private institutions and farmers that work in the very same field. Charitable institutions tend to operate less efficiently compared to its private competitor. Waqf institution as Islamic charitable institution must have a mindset of a private institution that targets profit and work efficiently, but does not forget its main role as charitable institution. The waqf institution must work under the jargon: "Profit based institution serving social, religious, and charitable purposes".

\section{Justification of the Concept}

Waqf is providing all necessary requirements (land, equipment, seed, fertilizer, etc) for the agriculture businesses it dealt with farmers. In short, waqf is becoming a capital provider for the farmers and gives subsidies for the farmers through lowering its profitsharing ratio or selling the farming necessities on discount. In addition, by creating new businesses, waqf is directly opens job opportunities for many, and providing income for not only those who were originally farmers, but to other job seeker who desperately needs work to sustain themselves and their families (Amuda et al, 2014; Shafiai et al, 2015; Puspitasari, 2017). Thus, the job created by waqf may provide panacea for both unemployment and poverty issues without the help of government or private sector, because essentially, the source of waqf assets and wealth come from wealthy moslem who wish to contribute to their family members and community even after the waqf giver has passed away.

Aside from providing jobs and improving the welfare of farmers, this waqf-syirkah concept indirectly influences food security in the long run. Logically, as Puspitasari (2017) mentioned, the utilization of idle waqf land for the production of rice in Indonesia will push the price down, because of rice abundance due to increased production. This concept is attempting to replicate on the concept proposed by both Abdelhady (2017) and Puspitasari (2017) but with some modifications to ensure that the goal on providing food security in the sense that essential food crops (main diet) of the community is in abundance, accessible, and available by all.

\section{Conclusions}

The concept of Waqf-syirkah is aimed to help farmers to do their farming and agribusiness activities, thus helping the community to ensure adequate supply and accessible food. 
This concept is also aimed to tackle financing problems faced by farmers, because the spearhead of this concept is the cooperation (syirkah) between waqf as capital provider and farmers as the working partner. It is commonly known that farmers are mostly categorized as un-bankable and unable to access financing. With waqf providing the capital and without collateral and interest financing, farmers may reap optimum profit from their activities and then it will be shared with waqf as their partner. In the long term, it is expected that this venture will result in strengthening food security locally and on a larger scale.

Furthermore, the cooperation between waqf and farmers may result in the creation of job opportunities, not only in the agriculture sector, but also other sectors that support it, thus reducing unemployment and improving the socio-economic status of people.

This concept tries to give solutions from the supply side by helping farmers as the grower and producer of staple food, providing necessary capital for them to plant staple food and other important crops. Logically, when the supply of staple food is stable, it will result in the stability of its price too, although there are several other factors that must be included to obtain complete framework for keeping the supply and price of staple food stable, which leads to the ultimate goal of this concept: availability and accessibility of food for all. The other factors such as nature, distribution costs, inflations, and others must also take into account to develop further sophisticated framework of this concept. With this concept, the community itself may provide help for their own people without the help of the government which ultimately burdens its national budget and taxpayers, creating a self-sustainable community based on waqf and partnership.

\section{References}

Abdelhady, H. (2012). Islamic Finance as a Strategic Mechanism for Bolstering Food Security in the Middle East. Sustainable Development Law \& Policy, 13(1), 1-15.

Andreas, H.H., \& Wohon, K. (2019). Corporate Social Responsibility of Sharia Banking in Indonesia. Journal of Business and Finance in Emerging Markets, 2(2), 127-140.

Amuda, Y.J., Embi, A.C., \& Babatunde, O.H. (2014). An Agricultural Approach to the Commercialization of Cash Waqf between Malaysia and Nigeria. Journal of Advanced Management Science, 2(4), 344-348.

Ashur, M.T.I. (2006). Treatise on Maqasid al-Shari'ah. Translated by Mohamed El-Tarih El-Mesawi. Herndon: The International Institute of Islamic Thought.

Bidabad, B. (2019). General Regulatory Framework in Rastin Profit and Loss Sharing Banking: (Part III-Auxiliary Provisions). Journal of Business and Finance in Emerging Markets, Vol. 2, No. 1, pp. 51-66.

Choudhury, M.A., \& Malik, U.A. (1992). The Foundations of Islamic Political Economy. London: The Macmillan Press Ltd.

Çizakça, M. (1998). Awqaf in History and Its Implications for Modern Islamic Economies. Islamic Economics Studies, 6(1), 43-70.

Cordero, M. (2016). Food Security and Livelihoods. Terre Des Homme: Lausanne. https://www.tdh.ch/sites/default/files/tp_fsl_tdh_en.pdf. 
HOLISTICA Vol 12, Issue 1, 2021, pp.76-88

Economist Intelligence Unit (2019a). “Global Food Security Index 2019". Accessed 15 November 2020.https://foodsecurityindex.eiu.com/Home/DownloadResource?fileName=Global\%20F ood\%20Security\%20Index\%202019\%20report.pdf

Economist Intelligence Unit (2019b). "Global Food Security Index 2019: Water Security is Food Security (Infographic)". Accessed $15 \quad$ November 2020. https://foodsecurityindex.eiu.com/Home/DownloadResource?fileName=22092020_EIU_G FSI_Water_v1_compressed.pdf

Economist Intelligence Unit (2019c). "Global Food Security Index 2019: Exploring Challenges, Developing Solutions (Infographic)". Accessed 15 November 2020. https://foodsecurityindex.eiu.com/Home/DownloadResource?fileName=041219_EIU_GFS I_web_v1-compressed.pdf

Food and Agriculture Organisation (2006). "Food Security Policy Brief". Issue.2. Food and Agriculture Organisation Agriculture and Development Economics Division. http://www.fao.org/fileadmin/templates/faoitaly/documents/pdf/pdf_Food_Security_Co cept_Note.pdf

Ghosh, D. (2020). Nutraceuticals in Brain Health and Beyond. London: Elsevier.

Islahi, A.A. (1996). Provision of Public Goods: Role of Voluntary Sector (Waqf) in Islamic History. In Financing Development in Islam. Jeddah: IRTI-IDB, 367-391.

Kahf, M. (n.d). Public Sector Economics from Islamic Perspective. Accessed 15 June 2018. http://monzer.kahf.com/papers/english/public_sector_economics.pdf.

Kahf, M. (2016). Waqf: a Quick Overview. Accessed 15 June 2018. http://monzer.kahf.com/papers/english/WAQF_A_QUICK_OVERVIEW.pdf

Khan, M.A. (1984). Islamic Economics: Nature and Need. Journal of King Abdulaziz University: Islamic Economics, Vol.1, No. 2, 1984. https://ssrn.com/abstract=3118130

Moh'd, I.S., Mohammed, M.O., \& Saiti, B. (2017). The problems facing agricultural sector in Zanzibar and the prospects of Waqf-Muzar'ah-supply chain model. Humanomics, 33(2), 189-210.

Mulawarman, Aji. Dedi., Kamayanti, Ari., Manzilati, Asfi., Djalaluddin, Ahmad., Sonhaji., Tumirin., Anggraeni, Fadjar Setiyo., Nurindrasari, Diana. (2018a). Akuntansi Syariah Untuk Rumah Sakit: Teori, Prinsip, dan Praktik. Depok: Rajawali Press.

Mulawarman, Aji. Dedi., Manzilati, Asfi., Djalaluddin, Ahmad., Kamayanti, Ari., Herlambang, Leo., Triyuwono, Iwan., Lutfillah, Novrida. Qudsi., Abdurahim, Ahim., Birton, Nur., Anggraeni, Fadjar Setiyo., Sonhaji., Luayyi, Sri., Darwanto., Kusdewanti, Amelia Indah., Viphindratin, Sebastiana., Marwin., Murtiyani, Siti., Syihab, Muhammad. Baiquni., Fatimah, Rika., ... Ekasari, Kurnia. (2018b). Kesejahteraan Semesta. Jakarta: Yayasan Rumah Peneleh.

Nasr, S.H., Dagli, C.K., Dakake, M.M., Lumbard, J.E.B., Rustom, M. (eds) (2015). The Study Quran: A New Translation and Commentary. New York: HarperCollins publishers.

Negi, C.S. (2005). "Religion and biodiversity conservation: not a mere analogy". International Journal of biodiversity science and management, 1, 85-96.

Noor, A.H.M., Sani, A.A., Hasan, Z.A., \& Misbahruddin, N.T. (2017). A Conceptual Framework for Waqf-Based Social Business from the Perspective of Maqasid Al-Shariah. International Journal of Academic Research in Business \& Social Sciences, 8(8), 801-818.

Palwak, K., \& Kolodziejczak, M. (2020). The Role of Agriculture in Ensuring Food Security in Developing Countries: Considerations in the Context of the Problem of Sustainable Food Production. Sustainability, 20, 1-20.

PEW Research Center. (2018, June 13). 3. How religious commitment varies by country among people of all ages. Accessed 10 November 2020. 
HOLISTICA Vol 12, Issue 1, 2021, pp.76-88

https://www.pewforum.org/2018/06/13/how-religious-commitment-varies-by-countryamong-people-of-all-ages/

Puspitasari, A.W. (2017). Optimizing Productive Land Waqf Towards Farmers Prosperity. Journal of Indonesian Applied Economics, 7(1), 103-112.

Raconteur (2017). Feeding the world: Future Food and Beverage. Accessed 01 November 2020. https://www.raconteur.net/infographics/feeding-the-world.

Shafiai, M.H.M., Moi, M.R., \& Ahmad, R. (2015). The potential of Waqf in Activating Idle Agricultural Land. Jurnal Pengurusan, 44, 141-147.

Shinkafi, A.A., \& Ali, N.A. (2017). Contemporary Islamic Economic Studies on Maqasid Shari'ah: A Systematic Literature Review. Humanomics, 33(3), 315-334.

Wildana, M.D.A. (2018). Role of Agriculture Waqf as Food Security Strategy and Price Stabilisation Policy of Rice: The Case of Indonesia. (Unpublished Master's Thesis). International Islamic University Malaysia, Kuala Lumpur, Malaysia. 